\title{
On the relationship between molecular mass and anticoagulant activity in a low molecular weight heparin (enoxaparin)
}

Citation for published version (APA):

Bendetowicz, A-V., Pacaud, E., Beguin, S., Uzan, A., \& Hemker, H. C. (1991). On the relationship between molecular mass and anticoagulant activity in a low molecular weight heparin (enoxaparin). Thrombosis and Haemostasis, 67(5), 556-562. https://doi.org/10.1055/S-0038-1648493

Document status and date:

Published: 01/01/1991

DOI:

10.1055/S-0038-1648493

Document Version:

Publisher's PDF, also known as Version of record

\section{Please check the document version of this publication:}

- A submitted manuscript is the version of the article upon submission and before peer-review. There can be important differences between the submitted version and the official published version of record. People interested in the research are advised to contact the author for the final version of the publication, or visit the DOI to the publisher's website.

- The final author version and the galley proof are versions of the publication after peer review.

- The final published version features the final layout of the paper including the volume, issue and page numbers.

Link to publication

\footnotetext{
General rights rights.

- You may freely distribute the URL identifying the publication in the public portal. please follow below link for the End User Agreement:

www.umlib.nl/taverne-license

Take down policy

If you believe that this document breaches copyright please contact us at:

repository@maastrichtuniversity.nl

providing details and we will investigate your claim.
}

Copyright and moral rights for the publications made accessible in the public portal are retained by the authors and/or other copyright owners and it is a condition of accessing publications that users recognise and abide by the legal requirements associated with these

- Users may download and print one copy of any publication from the public portal for the purpose of private study or research.

- You may not further distribute the material or use it for any profit-making activity or commercial gain

If the publication is distributed under the terms of Article $25 \mathrm{fa}$ of the Dutch Copyright Act, indicated by the "Taverne" license above, 


\title{
On the Relationship Between Molecular Mass and Anticoagulant Activity in a Low Molecular Weight Heparin (Enoxaparin)
}

\author{
Ana-Victoria Bendetowicz ${ }^{1}$, Elisabeth Pacaud ${ }^{2}$, Suzette Béguin ${ }^{1}$, André Uzan ${ }^{2}$, \\ and H. Coenraad Hemker ${ }^{1}$ \\ From the ${ }^{\top}$ Department of Biochemistry, Rijksuniversiteit Limburg, Maastricht, \\ The Netherlands and the ${ }^{2}$ Centre de Recherches de Vitry, Rhône-Poulenc Rorer, France
}

\section{Summary}

A low molecular weight heparin (enoxaparin, mean molecular weight $\sim 4,400$ ) was separated by gel chromatography into eight different fractions with a narrow distribution around the following mean molecular weights: $1,800,2,400,2,900,4,200,6,200,8,600$, 9,800 and 11,000 . We compared the influence of enoxaparin on the generation of thrombin in plasma to that of the eight fractions.

We determined: a) the \% of material with high affinity to antithrombin III (HAM) and the \% of HAM above the critical chainlength necessary to allow for thrombin inhibition (ACLM), b) the specific catalytic activity on the decay of endogenous thrombin, and c) the inhibition of over-all thrombin formation in the extrinsic and the intrinsic pathway. From $b$ and $c$ we calculated the inhibition of prothrombin conversion in these pathways.

We found that a) there is a gradual decrease of the HAM fraction with decreasing molecular weight; b) the specific catalytic activity for the inactivation of thrombin does not vary significantly between the fractions when expressed in terms of ACLM; c) the potency to inhibit prothrombin conversion does not vary significantly between the fractions when expressed in terms of HAM.

\section{Introduction}

Prevention of the appearance of free thrombin at a site where the blood coagulation mechanism is triggered is putatively the main mechanism by which antithrombotic pharmaceuticals exert their action (1). Heparins act by enhancing the inactivation of activated clotting factors by AT III. Heparin cofactor II is stimulated only at concentrations that are not usually attained in clinical practise. Consequently only those molecules that bind to AT III, i. e. the high affinity material (HAM), is capable to affect blood coagulation in a patient. Heparins loose their capacity to catalyse the AT III dependent inhibition of thrombin with decreasing molecular weight (2-6). Barrowcliffe et al. (5), and Thomas et al. (6) have shown that heparin fragments with a chainlength of 10-18 monosaccharide units have a high anti-factor $\mathrm{Xa}$ activity, and that a length of $20-22$ saccharides is minimally required for an antithrombin activity. Lane and coworkers (4) studied heparins of 8 to $>18$ monosaccharides and concluded that 18 units is the smallest chainlength that will allow to potentiate the inactivation of thrombin, shorter species catalysing factor Xa inactivation only. So all the HAM in a heparin has antifactor Xa acitivity, whereas antithrombin activity is expressed in HAM above the critical chainlength of 18 monosaccharides (ACLM) only. It therefore appeared logical that low molecular weight heparins should owe their antithrombotic action at least in

Correspondence to: Dr. H. C. Hemker, Department of Biochemistry, University of Limburg, P. O. Box 616, 6200 MD Maastricht, The Netherlands part to their anti-factor Xa activity. From there it was a small step to surmise that LMWHs with a high ratio of anti-factor Xa- to antithrombin activity could make better antithrombotics than conventional, unfractionated heparins (7).

The inhibitory actions of a heparin measured on isolated factors do not, however, necessarily directly reflect its activities in the complex medium of plasma (8-11). In order to study the effects of heparins under the conditions prevailing in clotting plasma, a method has been developed in our laboratory that allows the calculation of the conversion rate of prothrombin, independent of the simultaneous breakdown of the thrombin generated (8). By this approach it could be shown that:

1. Unfractionated heparin (UFH) acts mainly by enhancing thrombin breakdown, its effect on the inhibition of prothrombinase in the extrinsic pathway is of minor importance (12).

2. The synthetic pentasaccharide (PS) that represents the AT IIIbinding site of heparin (13), and that does not catalyse direct inhibition of thrombin (14), unlike UFH does inhibit prothrombinase via its action on inhibition of free factor Xa (15).

3. Most low molecular weight heparins (LMWHs) act rather like standard heparin, in that they have a minor influence on the prothrombinase activity in plasma, even though the anti-factor $\mathrm{Xa}$ /antithrombin ratio is reported to be high (16).

One of the LMWH preparations that we studied, PK 10169 or enoxaparin, caused a relatively high inhibition of prothrombin conversion. This has previously been explained as being caused by a high proportion of pentasaccharide like material (17). In this study we want to establish what material in enoxaparin is responsible for its over-all action on blood coagulation. To this end we prepared from enoxaparin eight fractions with largely different average molecular weight (MW) and a narrow MW distribution. We studied the anti-thrombin and anti-prothrombinase properties as a function of the HAM and the ACLM content of these fractions.

\section{Materials and Methods}

\section{Materials}

Three batches of the low molecular weight heparin enoxaparin $(88.145 .02 ; 89.009 .01 ; 89.037 .01)$ were supplied by Rhône-Poulenc Rorer: They were prepared from heparin by chemical $\beta$-elimination. Three runs were performed with different batches of heparin. The average MW of the three batches of enoxaparin were around 4,400,4,500, and 4,500 respectively. Their anti-factor $\mathrm{Xa}$ activities $(18,19)$ were 115,120 and $108.5 \mathrm{IU} / \mathrm{mg}$. Their activity in the European pharmacopoeia method (i. e. an activated partial thromboplastin time in sheep plasma) was 56.3, 66 and $57 \mathrm{IU} / \mathrm{mg}$ respectively.

From one of these batches (88.145.02) eight fractions with narrow MW distribution were obtained (see Methods).

The chromogenic substrate for thrombin, H.D-Phe-Pip-Arg-pNA (S2238), was obtained from Kabi, Sweden. Kaolin (Kaolin léger) was provided by B. L. B. Laboratoires du Bois de Boulogne (Puteaux, France). 
Buffer A: $0.05 \mathrm{M}$ Tris- $\mathrm{HCl}, 0.1 \mathrm{M} \mathrm{NaCl}, 0.5 \mathrm{mg} / \mathrm{ml}$ human serum albumin, $\mathrm{pH} 7.35$.

Buffer B: $0.05 \mathrm{M}$ Tris- $\mathrm{HCl}, 0.1 \mathrm{M} \mathrm{NaCl}, 0.5 \mathrm{mg} / \mathrm{ml}$ human serum albumin with $20 \mathrm{mM}$ EDTA at $\mathrm{pH} 7.90$.

\section{Plasma}

Blood from ten healthy donors was collected on $0.13 \mathrm{M}$ trisodium citrate; nine parts of blood to one part of citrate solution. A first and a second centrifugation were done at $15^{\circ} \mathrm{C}$, during $15 \mathrm{~min}$ at $3,000 \times \mathrm{g}$, and a third centrifugation was done at $4^{\circ} \mathrm{C}$, for 1 hour at $23,000 \times \mathrm{g}$. The platelet free plasma thus obtained was stored at $-80^{\circ} \mathrm{C}$. It was checked that the clotting factors and the antiproteases were in the normal range. Defibrinated plasma was obtained by mixing an aliquot of plasma with $1: 50$ volume of a reptilase solution, letting a clot form for $5 \mathrm{~min}$ at $37^{\circ} \mathrm{C}$, and keeping the clotted plasma at $4^{\circ} \mathrm{C}$ for $10 \mathrm{~min}$. The fibrin formed was discarded by winding it on a small plastic spatula. As it was previously shown, the concentration of factors II, VII, VIII, IX, X, XI and XII does not change significantly by the reptilase treatment (8).

\section{Proteins}

Reptilase was obtained from Bochringer Mannheim (Mannheim, Germany) and dissolved according to the instructions of the manufacturer. Soybean Trypsin Inhibitor, (batch No. 43 F 8000) was obtained from Sigma (St. Louis, MO). Staphylocoagulase was obtained from Laboratoires Stago (Asnières, France) and reconstituted according to the instructions of the manufacturer. Human AT III was a gift of Prof. H. Goudemand (Lille, France). It had been prepared by polyethylene glycol precipitation of barium citrate-adsorbed plasma and affinity chromatography on a heparin-sepharose column (20). The AT III was subsequently freed of remaining heparin by ion exchange chromatography (21). Its activity was assessed by titration with active site titrated factor Xa (22). Human brain thromboplastin was prepared according to Owren and Aas (23). Before use it was diluted with buffer A containing $0.1 \mathrm{M} \mathrm{Ca}^{2+}$ so as to clot in $70-80 \mathrm{~s}$ a mixture of $120 \mu \mathrm{l}$ of plasma, $30 \mu \mathrm{l}$ of thromboplastin and $30 \mu \mathrm{l}$ of buffer $\mathrm{A}$.

\section{Methods}

\section{Heparin Fractionation}

From one of the enoxaparin batches (88.145.02) eight fractions with narrow molecular weight distribution were obtained by gel permeation chromatography on ACA 202 and ACA 54 (Tables 1 and 2). The mobile phase was $0.33 \mathrm{M} \mathrm{NaCl}$. The average molecular weight of the fractions obtained (N6 to N36) was determined by High Performance Size Exclusion Chromatography (HPSEC) coupled with Laser Light Scattering. In addition, we estimate the average number of disaccharidic units per chain by ${ }^{13} \mathrm{C}$ NMR analysis (24). The narrow elution protiles and the ratio of weight average to number average molecular weights of close to unity indicated a limited degree of polydispersity. HPSEC was performed on a system that consists of a Gilson 302 pump, an RID 6 A differential refractometer (Shimadzu) and an SF UV detector (Kratos). Aqueous solutions of enoxaparin at $10 \mathrm{mg} / \mathrm{ml}$ were analysed on a two-column system (TSK G 3000 SW- $30 \times 0.75 \mathrm{~cm}$ and Lichrosorb 100 diol $25 \times$ $0.75 \mathrm{~cm})$. The mobile phase $(0.3 \mathrm{M}$ phosphate buffer, $\mathrm{pH}$ 7) was used at flow rate $0.75 \mathrm{ml} / \mathrm{min}$. Due to the narrow distribution of the fractions, they were used to calibrate the chromatographic system used subsequently for the determination of the MW of enoxaparin. This was determined by HPSEC coupled with refractometry.

\section{Fluorescence Measurements}

The molar concentrations of the HAM in each isolated fraction were determined by a stoichiometric titration of AT III $(0.5 \mu \mathrm{M})$ in buffer (Tris $\mathrm{HCl} 50 \mathrm{mM}, \mathrm{NaCl} 0.1 \mathrm{M}, \mathrm{pH} 7.5$ ) as described in ref. (25). Briefly, the binding of a heparin fraction to Antithrombin III results in an increase of the tryptophan fluorescence of the protein (excitation at $285 \mathrm{~nm}$, emission at $345 \mathrm{~nm}$; ref. 26). The fluorescence increase is calculated as $\left(F-F_{0}\right) /$ $F_{\mathrm{m}}-F_{\mathrm{o}}$, where $F$ is the fluorescence intensity of the sample containing heparin, $F_{\mathrm{o}}$ that of the control solution without heparin, and $F_{\mathrm{m}}$ is the fluorescence obtained at the saturation concentrations. The fluorescence increase can subsequently be plotted as a function of the heparin concentration (in $\mu \mathrm{g} / \mathrm{ml}$ ). Upon addition of increasing amounts of heparin, the fluorescence of AT III increases proportionally with the heparin concentration until the equivalence point has been reached. The concentration of the heparin fraction at the inflection point (in $\mu \mathrm{g} / \mathrm{ml}$ ), contains the number of binding sites present in the AT III added, i. e. $0.5 \mu \mathrm{M}$. It should be noted that this determination is independent of the magnitude of the fluorescence change, i.e. independent of possible changes of fluorescence with the chainlength of the heparin. The AT III itself has been titrated with synthetic pentasaccharide that is assumed to contain $100 \%$ high affinity material. In this way one obtains the molar concentration of binding sites per mg of heparin. Knowing the MW of the heparin we can then calculate the percentage of high affinity molecules in the heparin preparation. The titration was carried out on a SLM Aminco SPF$500 \mathrm{C}$ spectrofluorometer.

\section{Rate Constants of Inactivation of Endogenous Thrombin}

Defibrinated plasma $(120 \mu \mathrm{l})$ is mixed with buffer $\mathrm{A}(14 \mu \mathrm{l})$, and prewarmed for 5 minutes at $37^{\circ} \mathrm{C}$. Thrombin generation is started by the addition of $30 \mu \mathrm{l}$ of thromboplastin dilution. Two minutes after the peak activity of thrombin, $6 \mu \mathrm{l}$ of a $10 \mathrm{mg} / \mathrm{ml}$ Soybean Trypsin Inhibitor (SBTI) solution (8), is added together with $10 \mu \mathrm{l}$ of buffer that contains the heparin to be tested. At suitable intervals after this addition $10 \mu \mathrm{l}$ aliquots of the incubation mixture are transferred to cuvettes containing $0.2 \mathrm{mM}$ of S-2238 in $490 \mu$ l of buffer B, to measure residual thrombin activity. After $120 \mathrm{~s}$, the reaction in the cuvette is stopped by adding $300 \mu \mathrm{l}$ of concentrated acetic acid. The pseudo-first order rate constant of inhibition

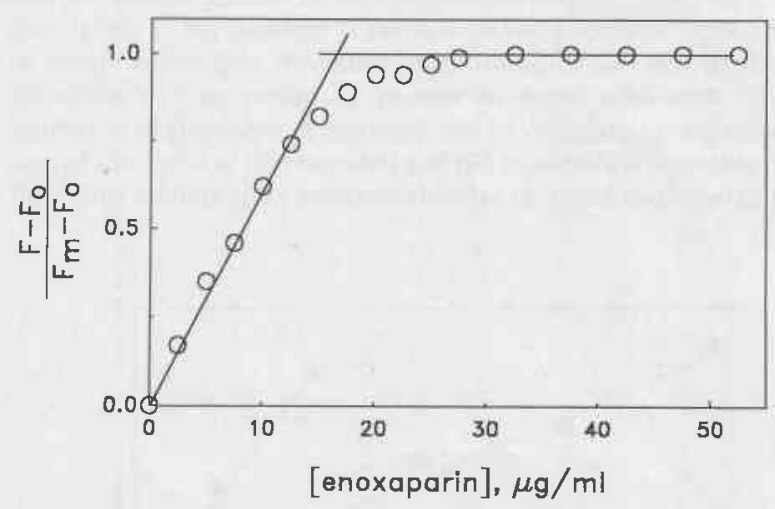

Fig. 1 Fluorescence titration of AT III with enoxaparin. The fluorescence increase of $0.5 \mu \mathrm{M}$ AT III is calculated as indicated in the methods section. At the equivalence point the concentration of enoxaparin was $16 \mu \mathrm{g} / \mathrm{ml}$

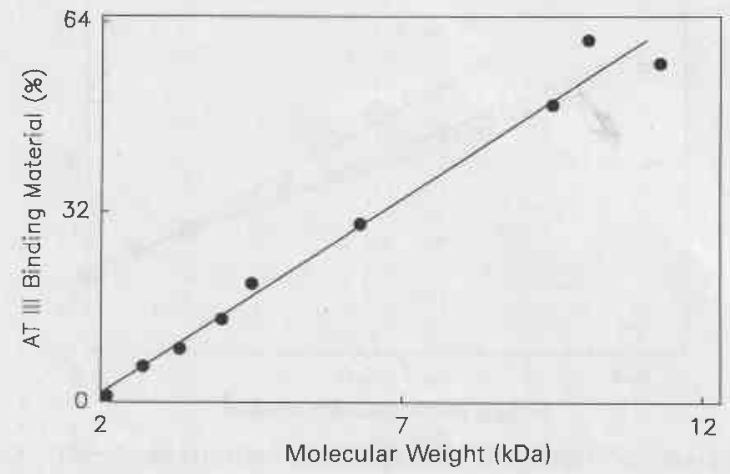

Fig. 2 High affinity heparin fraction as a function of molecular weight. The percentage of HAM was obtained from the fluorometric titration of AT III (Table 2), and the molecular weight from the data shown in Table 1 
Table 1 Properties of the enoxaparin fractions

\begin{tabular}{|c|c|c|c|c|c|c|c|}
\hline \multirow[t]{2}{*}{ Heparin } & \multicolumn{3}{|l|}{ HPLC } & \multicolumn{2}{|c|}{ NMR } & \multirow[t]{2}{*}{$N_{\text {est }}$} & \multirow{2}{*}{$\begin{array}{l}\text { ACLM } \\
\%\end{array}$} \\
\hline & MW & $W / N$ & $N$ & $N$ & $\mathrm{~S} / \mathrm{Cx}$ & & \\
\hline N6 & 1,800 & 1.08 & 6.2 & 7 & 2.4 & 6 & $<3$ \\
\hline N8 & 2,400 & 1.02 & 8.0 & 9 & 2.4 & 8 & $<3$ \\
\hline N10 & 2,900 & 1.02 & 9.7 & 10.8 & 2.2 & 10 & 3 \\
\hline N14 & 4,200 & 1.01 & 14.0 & 14.5 & 2.2 & 14 & 10 \\
\hline N20 & 6,200 & 1.01 & 20.7 & 20.8 & 2.0 & 20 & 67 \\
\hline N28 & 8,600 & 1.01 & 28.1 & - & - & 28 & $>95$ \\
\hline N32 & 9,800 & 1.03 & 32.7 & - & - & 32 & $>95$ \\
\hline N36 & 11,000 & 1.05 & 36.6 & - & - & 36 & $>95$ \\
\hline
\end{tabular}

HPLC: data from high performance liquid chromatography; NMR: data from nuclear magnetic resonance; MW: weight average molecular weight; $W / N$ : ratio of weight and number average molecular weight; $N$ : number of monosaccharide units. S/Cx gives the ratio of sulfate/carboxyl. $N_{\text {est }}$ gives the number of monosaccharides of the main component of the fraction assessed from the experimental data, and knowing it to be an even integral number. ACLM $\%$ gives the percentage of material with a MW $>5.4 \mathrm{kDa}$.

Table 2 AT III binding material of the enoxaparin fractions

\begin{tabular}{lccc}
\hline Heparin & $\begin{array}{l}\text { IPC } \\
(\mu \mathrm{g} / \mathrm{ml})\end{array}$ & $\begin{array}{l}\text { BS } \\
(\mu \mathrm{M} / \mathrm{mg})\end{array}$ & $\begin{array}{l}\text { HAM } \\
(\%)\end{array}$ \\
\hline N6 & 114 & 8.8 & 1 \\
N8 & 36 & 27 & 6 \\
N10 & 31 & 32 & 9 \\
N14 & 21 & 48 & 20 \\
N20 & 10 & 50 & 30 \\
N28 & 9 & 55 & 50 \\
N32 & 8 & 62 & 61 \\
N36 & 10 & 52 & 57 \\
enox & 16 & 31 & 14 \\
\hline
\end{tabular}

IPC: Concentration of heparin at the inflection point, necessary to saturate the $0.5 \mu \mathrm{M}$ of AT III present in the experiment. BS: Binding site content of heparin calculated $(\mu \mathrm{M} / \mathrm{mg})$. HAM: The percentage of antithrombin III high affinity molecules calculated from the binding site content and the molecular weight.

Table 3 Specific anti-thrombin activities

\begin{tabular}{llccl}
\hline Heparin & Total & HAM & ACLM & ACLM $^{*}$ \\
\hline Enoxaparin & 1.05 & 7.5 & 12.3 & - \\
N6 & 0 & 0 & 0 & - \\
N8 & 0 & 0 & 0 & - \\
N10 & 0 & 0 & 0 & - \\
N14 & 0.07 & 0.35 & 3.5 & - \\
N20 & 3.30 & 11 & 16.3 & 2.63 \\
N28 & 6.14 & 12.3 & 12.3 & 1.34 \\
N32 & 6.69 & 10.8 & 10.8 & 1.10 \\
N36 & 9.62 & 16.9 & 16.9 & 1.35 \\
\hline
\end{tabular}

*) The activities are expressed in $\min ^{-1}(\mu \mathrm{g} / \mathrm{ml})^{-1}$ except for the last column that is in $\min ^{-1} \mathrm{nM}^{-1}$

of thrombin generated in plasma is calculated by fitting the data to

$C_{t}=C_{\mathrm{R}}+C_{\mathrm{o}} \mathrm{e}^{-k t}$,

where $C_{t}$ is the thrombin activity at time $t, C_{\mathrm{R}}$ is the steady end-level activity, $C_{\mathrm{o}}+C_{\mathrm{R}}$ is the amidolytic activity at the time of SBTI addition. The observed decay constant is the sum of two constants, $k=k_{1}+k_{2}$; $k_{1}$ is the AT III-dependent decay constant of inhibition of thrombin, $k_{2}$ is the decay constant of inhibition of thrombin by $\alpha_{2}$-macroglobulin $\left(\alpha_{2}-\mathrm{M}\right)$. The ratio of $k_{1}$ to $k_{2}$ is determined as the ratio of the amounts of thrombin complexed with AT III and $\alpha_{2}-\mathrm{M}$ as described previously (8). From their sum and their ratio the constants are calculated. $k_{1}$ in all instances is lineary dependent upon the heparin concentration, so the second order rate constants of thrombin inhibition could be obtained from the pseudo- first order rate constants by calculating the increase of $k_{1}$ per $\mu \mathrm{g}$ of heparin. $k_{2}$ appeared not to be dependent on the amount of heparin added.

\section{Thrombin Generation in Plasma}

$240 \mu \mathrm{l}$ of defibrinated plasma is supplemented with $60 \mu \mathrm{l}$ of buffer A, containing heparin at the desired concentration and incubated for $5 \mathrm{~min}$ at $37^{\circ} \mathrm{C}$. At zero time, thrombin generation is started by the addition of $60 \mu \mathrm{l}$ of a solution containing $100 \mathrm{mM}$ of $\mathrm{CaCl}_{2}$, and a trigger of coagulation. For the extrinsic system this is human brain thromboplastin, as described in the previous section. For the intrinsic system, $1 \mu \mathrm{M}$ phospholipid and $0.025 \mathrm{mg}$ kaolin (final concentration). At intervals, a $10 \mu \mathrm{l}$ aliquot of the mixture is sampled into a disposable plastic cuvette containing buffer and chromogenic substrate, as described above. The optical density is measured at $405 \mathrm{~nm}$. The amidolytic activities in the plasma samples are calculated from the O.D., and expressed as the equivalent concentration of thrombin (in $\mathrm{nM}$ ), according to a reference curve obtained with active site titrated purified human $\alpha$-thrombin. From the curves of amidolytic activity the thrombin concentrations were obtained as previously described (8). Of each heparin species a series of concentrations was tested so as to find that one (IC25) that inhibits the peak of generated thrombin by $25 \%$. The unconventional IC25 was choosen rather than IC50 in order to allow comparison with the IC25 of prothrombinase (see results section).

\section{Prothrombinase Activity in Plasma}

The generation of prothrombinase activity is calculated from the amidolytic activity curve thrombin generation as described previously (8). Briefly, the observed amidolytic activity is the sum of thrombin activity and the partial activity of $\alpha_{2} \mathrm{M}$-thrombin complex. The rate of thrombin generation at any moment is the sum of two processes: a) the conversion of prothrombin into thrombin by prothrombinase and b) the decay of thrombin by the action of plasma protease inhibitors. The rate of inhibition of thrombin at any time can be calculated from the concentration of thrombin at that moment and the pseudo-first oder rate constant of thrombin inhibition by antithrombin III $\left(k_{1}\right)$ and $\alpha_{2}$-macroglobulin $\left(k_{2}\right)$.
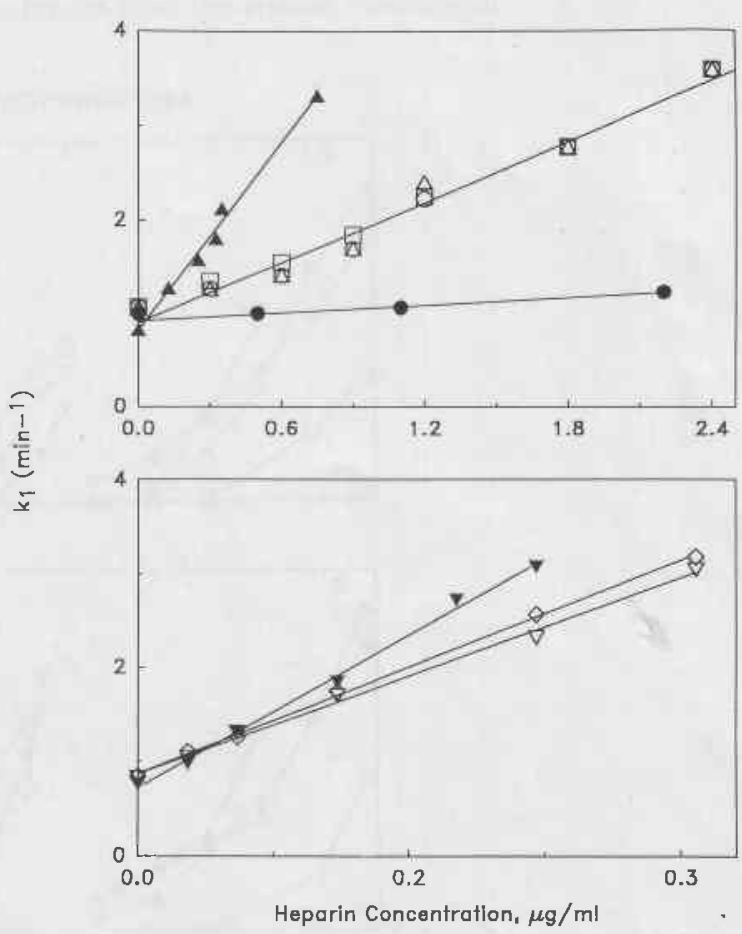

Fig. 3 The decay constant of endogenous thrombin in normal plasma as a function of the heparin concentration. The specific anti-thrombin activities of the heparins (see text) are obtained from the slopes of these lines. Upper frame: Open symbols: Enoxaparin (three batches); •: N14; $\Delta$ : N20. Lower frame: $\nabla: \mathrm{N} 28 ; \diamond: \mathrm{N} 32 ; \boldsymbol{\nabla}: \mathrm{N} 36$ 
The rate of prothrombin activation (prothrombinase activity) then can be calculated from the observed rate of generation of amidolytic activity and the rate of thrombin inhibition.

\section{Results}

\section{Physicochemical Properties and AT III Affinity of the Fractions}

Table 1 summarises the data obtained from the physicochemical characterisation of the fractions. The ratio of near unity of the weight average to the number average molecular weight demonstrates the narrow distribution of the MW of these fractions. Also in Table 1 one finds the chainlength as calculated from the HPLC data on basis of a mean MW of 300 per monosaccharide unit, as well as the chainlength obtained from the ${ }^{13} \mathrm{C}$ NMR data. From these two parameters, and knowing that theoretically the chainlength has to be an even integral number, we estimated the most probable number of monosaccharide units for the major part of the material ( $N_{\text {est }}$ in Table 1). A complete interpretation of the ${ }^{13} \mathrm{C}$ NMR spectra also provided the degree of substitution of enoxaparin fractions by sulfate residues (sulfate/carboxyl ratio). We also calculated the amount of material with a $\mathrm{MW}>5,400$ from HPLC profiles.

The titration of AT III with the heparins permitted to calculate the active concentration of heparin at the equivalence point. Subsequently the percentages of material with high affinity for AT III (HAM) found in the different fractions were obtained (Table 2). Fig. 1 shows the stoichiometrical titration of AT III with enoxaparin. As can be seen from Fig. 2, the percentage of HAM seems to decrease linearly with decreasing mean size of the heparin molecule.

\section{The Specific Antithrombin Activity}

The effect of increasing concentrations of the heparins on the pseudo-first order decay constant of endogenous thrombin was determined. For each of the preparations the constant increased linearly with the concentration of the heparin (Fig. 3). From the slope of these lines we determined the specific activity of the heparins (Table 3). We define the specific acitivty of a heparin as the increase of the decay constant of thrombin in plasma per $\mu \mathrm{g} /$ $\mathrm{ml}$ of heparin. (It can also be expressed per nanomole in those preparations of well defined molecular weight. A specific antifactor Xa activity can be defined analogously). Reasoning that the activity is caused by molecules with a high affinity to AT III and above the critical chainlength of 18 monosaccharide units, we calculated the specific activities of both the HAM and the ACLM in the fractions. The specific activity of enoxaparin is $1.050 \mathrm{~min}^{-1} \mu \mathrm{g}^{-1} \mathrm{ml}$ (mean of three batches), which is close to the value of $1.110 \mathrm{~min}^{-1} \mu \mathrm{g}^{-1} \mathrm{ml}$ ) calculated from previous data (17). This amounts to $7.500 \mathrm{~min}^{-1}$ per $\mu \mathrm{g} / \mathrm{ml}$ of HAM and 31.250 per $\mu \mathrm{g} / \mathrm{ml}$ of ACLM.

\section{The Overall Inhibition of the Thrombin Peak}

The inhibitory activity of the heparin on the formation of free thrombin in clotting plasma is an over-all effect that can be due to both an increased decay of thrombin and an decreased prothrombin conversion. We can calculate (see methods section and ref. 8) what part of the over-all inhibition is to be attributed to inhibition of prothrombin conversion and what part to the acceleration of thrombin decay. This calculation is based on the observed thrombin activities and requires a minimum of $\sim 20 \%$ of residual thrombin activity to maintain the required accuracy. Half total inhibition of prothrombin conversion often occurs at $>80 \%$ inhibition of the thrombin peak. We therefore determined the concentration of heparin necessary to obtain $25 \%$ of the prothrombinase activity, and compared it to the heparin concentration that causes $25 \%$ inhibition of the thrombin peak (IC25, Table 4). This was done both in the extrinsic- and the intrinsic system (Fig. 4). The results were again expressed in terms of HAM. We did not present the results in lirms of ACLM, since prothrombinase inhibition is not necessarily confined to heparin molecules longer than the critical chainlength.
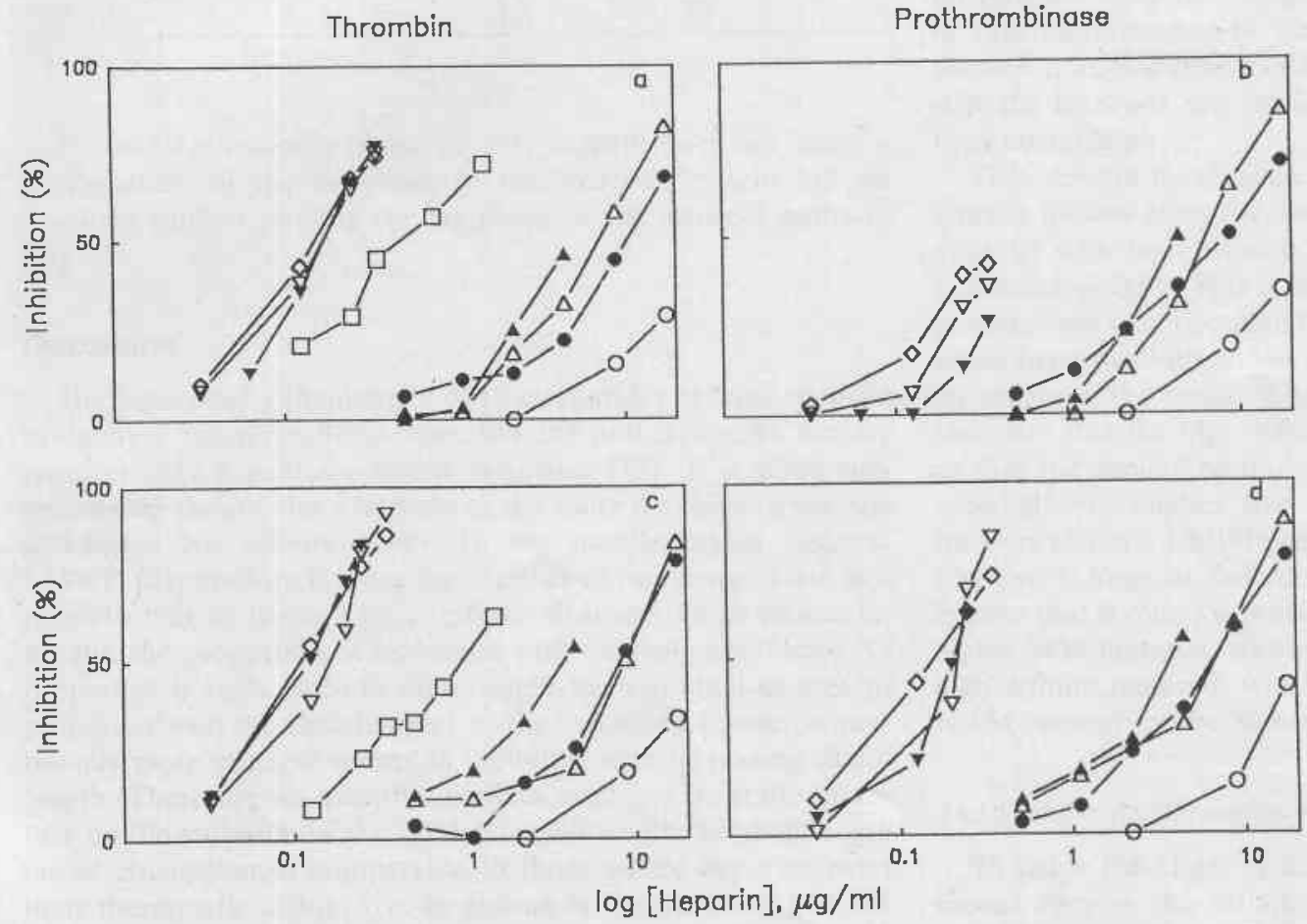

Fig. 4 The inhibition of thrombin and prothrombinase as a function of heparin concentration. For experimental details see methods section. Upper frames: extrinsic system; lower frames: intrinsic system. O: N6; $:$ N8; $\triangle: N 10 ; \Delta: N 14 ; \square: N 20 ; \diamond: N 28 ; \nabla: N 32 ; \nabla: N 36$ 
Table 4 Concentrations that cause $25 \%$ inhibition

\begin{tabular}{|c|c|c|c|c|c|}
\hline \multirow[t]{2}{*}{ Heparin } & \multicolumn{3}{|c|}{ Thrombin } & \multicolumn{2}{|c|}{ Prothombinase } \\
\hline & All & HAM & ACLM & All & HAM \\
\hline \multicolumn{6}{|c|}{ A1) Weight basis $(\mathrm{ng} / \mathrm{ml})$, extrinsic system } \\
\hline Enoxaparin & 450 & 63 & $(26)$ & 750 & 105 \\
\hline N6 & 15,800 & 158 & - & 15,800 & 158 \\
\hline N8 & 4,500 & 270 & - & 4,500 & 270 \\
\hline N10 & 3,400 & 306 & - & 3,400 & 306 \\
\hline N14 & 2,200 & 440 & 52 & 2,600 & 520 \\
\hline $\mathrm{N} 20$ & 200 & 60 & 40 & - & - \\
\hline $\mathrm{N} 28$ & 70 & 35 & 35 & 170 & 85 \\
\hline $\mathrm{N} 32$ & 80 & 50 & 50 & 210 & 130 \\
\hline N36 & 90 & 51 & 51 & 340 & 194 \\
\hline \multicolumn{6}{|c|}{ A2) Weight basis ( $\mathrm{ng} / \mathrm{ml})$, intrinsic system } \\
\hline Enoxaparin & 550 & 77 & $(32)$ & 750 & 105 \\
\hline N6 & 15,800 & 158 & - & 15,800 & 158 \\
\hline N8 & 4,400 & 264 & - & 4,400 & 264 \\
\hline N10 & 3,800 & 342 & - & 3,800 & 342 \\
\hline N14 & 1,600 & 320 & 32 & 1,600 & 320 \\
\hline $\mathrm{N} 20$ & 250 & 75 & 50 & - & - \\
\hline N28 & 50 & 25 & 25 & 75 & 37 \\
\hline N32 & 80 & 50 & 50 & 160 & 99 \\
\hline N36 & 60 & 34 & 34 & 130 & 74 \\
\hline \multicolumn{6}{|c|}{ B1) Molar basis ( $n M)$, extrinsic system } \\
\hline N6 & 8,780 & 88 & - & 8,780 & 88 \\
\hline N8 & 1,875 & 112 & - & 1,875 & 112 \\
\hline N10 & 1,170 & 106 & - & 1,170 & 106 \\
\hline N14 & 524 & 123 & 12 & 619 & 123 \\
\hline $\mathrm{N} 20$ & 32 & 10 & 7 & - & - \\
\hline $\mathrm{N} 28$ & 8 & 4 & 4 & 18 & 9 \\
\hline N32 & 8 & 5 & 5 & 21 & 13 \\
\hline N36 & 8 & 5 & 5 & 27 & 16 \\
\hline \multicolumn{6}{|c|}{ B2) Molar basis (nM), intrinsic system } \\
\hline N6 & 8,780 & 88 & - & 8,780 & 88 \\
\hline N8 & 1,830 & 110 & - & 1,830 & 110 \\
\hline N10 & 1,310 & 118 & - & 1,310 & 118 \\
\hline N14 & 380 & 76 & 7.6 & 380 & 76 \\
\hline N20 & 40 & 12 & 8 & - & - \\
\hline $\mathrm{N} 28$ & 6 & 3 & 2.7 & 8 & 4 \\
\hline N32 & 8 & 5 & 5.1 & 16 & 10 \\
\hline N36 & 5 & 3 & 2.7 & 10 & 6 \\
\hline
\end{tabular}

It was systematically observed that heparin does not cause a prolongation of the lag-phase in the extrinsic system but all fractions studied prolong the lag-phase in the intrinsic pathway (Fig. 5).

\section{Discussion}

Heparins need a chainlength of 18 saccharides or more in order to catalyse thrombin breakdown but the anti-factor $\mathrm{Xa}$ activity requires only a pentasaccharide sequence (13). It is often suggested that the smaller a heparin is, the more it exhibits a specific anti-factor Xa activity (2-6). In the usually highly disperse LMWH preparations this can mean either of two things. First, is it possible that in heparin preparations with low mean molecular weight, the proportion of molecules with uniquely anti-factor Xa properties is high. Second there might be a gradual change of properties with the chainlength i.e. the heparins become proportionally more efficient thrombin inhibitors with increasing chainlength. There are no quantitative data available from the literature on the variation of the catalytic activity with the chainlength under circumstances comparable to those where heparins exert their therapeutic action, i. e. in plasma in the presence of $\mathrm{Ca}^{2+}$ ions, although it has been well documented that the effect of $\mathrm{Ca}^{2+}$ is important (27-29).
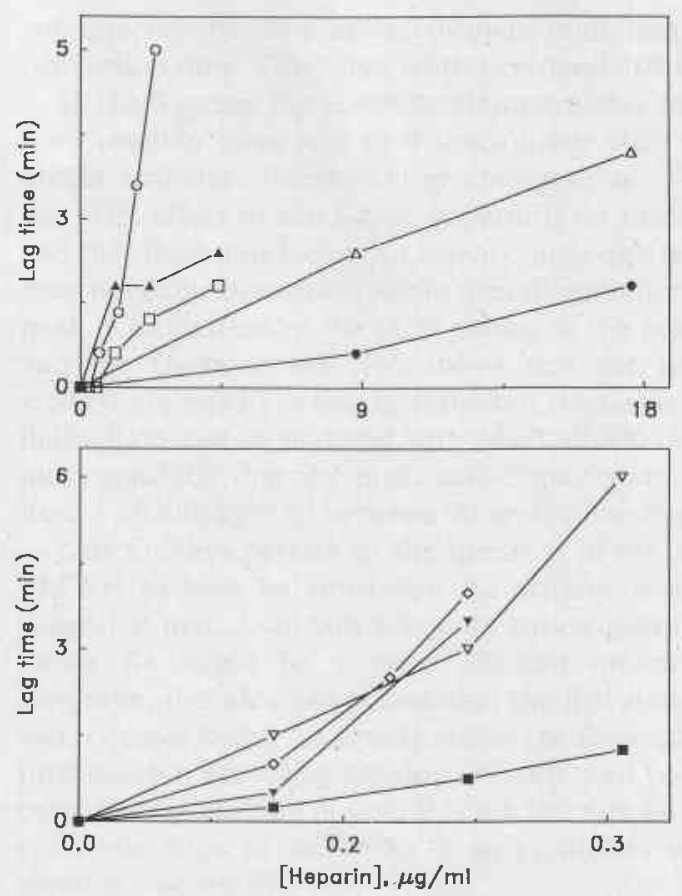

Fig. 5 The lag-phase of intrinsic thrombin generation as a function of heparin concentration. Upper frame: O: Enoxaparin; : N6; $\triangle$ : N8; $\Delta:$ N10; $\square:$ N14. Lower frame: $\square:$ N20; $\nabla:$ N28; $\mathbf{\nabla}:$ N32; $\diamond:$ N36

In this study, it was our aim to determine the effect of heparin chainlength on thrombin breakdown and prothrombin conversion under circumstances comparable to those in which heparins exhibit their therapeutic action, i.e. in clotting plasma. To this end we prepared a series of subfractions of the LMWH enoxaparin. These fractions appear to have a narrow molecular weight distribution, the ratio of weight average and number average molecular weight is near unity and the chainlength obtained by dividing the molecular weight through the mean molecular weight of one monosaccharide unit (300) gives a figure near to the number obtained from NMR measurements. We therefore think that the fractions are reasonably homogeneous with respect to their chainlength.

They remain heterogeneous as to chemical composition. This already follows from the observation that the relative amount of material with high affinity to AT III decreases with decreasing molecular weight. This is a logical consequence of the LMWH preparations being obtained by random fragmentation of conventional heparin. With an increasing of cleavages the mean molecular weight of the resulting product drops, but also the probability increases that the high affinity pentasaccharide region is severed so that the remaining molecule looses its HAM character. This automatically implies that the MW distribution of the HAM fraction within a LMWH cannot be the same as that of the total fraction. It must be shifted to the higher MW ranges. This again implies that it must be possible that isolation of a narrow zone of higher MW material from a LMWH will cause a relative gain of high affinity material, which explains that in some fractions the HAM content can be higher than in the original material.

\section{The Specific Antithrombin Activity}

To judge the effect of the molecular size on the activity, one should express the activities on basis of the amount of active material, i. e. in terms of high affinity material (HAM) and, when anti-thrombin activities are concerned in terms of high affinity 
material above the critical chainlength of 18 monosaccharide units (ACLM). In another study (30) we compared the specific activities of an ultralow-, low-, and middle molecular weight fractions of another LMWH (CY216) and the isolated high affinity material obtained from them. We could show that the specific activity of the isolated high affinity material is indistinguishable from that of the original materials when corrected for the non-affine material. We define the specific anti-thrombin activity as the increase of the pseudo-first order decay constant of endogenous thrombin in normal plasma brought about by $1 \mu \mathrm{g} / \mathrm{ml}$ of heparin. (Alternatively, with heparin preparations of well defined molecular weight, one can express the specific activity per nanomole.) If the specific activity were constant with unit weight this would mean that the catalytic activity of a heparin molecule increases proportionally with its length, if it would be constant per molar unit this would indicate that being longer than 18 monosaccharide units is a necessary and sufficient condition for a heparin molecule to express full antithrombin activity.

Table 3 gives the specific activities found. It is confirmed that only the fractions with a chainlength $>18$ saccharide units possess anti-thrombin activity. The heparins without significant antithrombin activity (fractions N6-N14) we call P-type heparins, the others S-type heparins (16). Within the S-type group, no significant systematic variation of the specific activity can be observed with the chainlength, neither when expressed on a weight- or on a molar basis. The data do not allow to distinguish between these two possibilities. A larger series of heparins with well defined chainlengths between 20 and 40 monosaccharide units will have to be available to settle that question.

\section{The Inhibition of Prothrombin Conversion}

The inhibition of extrinsic prothrombinase is a consequence of the inactivation of factor Xa. The inhibition of the intrinsic prothrombinase is a combined effect of factor $\mathrm{Xa}$ inactivation and inhibition of factor $\mathrm{X}$ activation (see below). The IC25 values for extrinsic prothrombinase inhibition, even when corrected for the non-affine material present, are lower for the S type heparins than for the $\mathrm{P}$ type materials. This is already clear when expressed on a weight basis and it is even more evident when they are expressed in molar units (Table 4). This shows that in plasma, in the presence of $\mathrm{Ca}^{2+}$ ions, the medium molecular weight heparin species are more potent inhibitors of factor Xa than the ultra-low species are. This was also observed in a purified system $(31,32)$. Within the $\mathrm{S}$ or the $\mathrm{P}$ group no systematic shift of the activity with the molecular weight can be observed. It is rather as if the difference that brings about the anti-thrombin activity also increases the antiprothrombinase (i. e. anti-factor $\mathrm{Xa}$ ) activity.

Table 4 suggests that the effect of the higher molecular weight species $(\geqslant \mathrm{N} 20)$ in enoxaparin on intrinsic prothrombinase activity is more important than on the extrinsic one. This can be explained by their antithrombin activity, on the thrombin dependent feedback activation of factor VIII $(12,16,34-36)$. This not only causes a prolongation of the lag-phase (Fig.5) but also prevents factor IXa from being protected by factor VIIIa, so that it is inactivated by AT III-heparin and less prothombinase is formed. This mechanism has been shown to be operative with unfractionated heparin (37).

\section{The Overall Inhibition of the Thrombin Peak}

The inhibition of the thrombin peak is the combined effect of inhibition of prothrombin conversion and enhancement of thrombin breakdown. Within the P group IC25 for thrombin inhibition is equal to that of prothrombinase inhibition, which is a logical consequence of their acting through inhibition of prothrombin conversion only. The value scatters around $100 \mathrm{nM}$ (Table 4).

In the $\mathrm{S}$ group the concentration necessary to inhibit for $25 \%$ the thrombin peak is 2 to 4 times lower than that required to obtain a similar inhibition of prothrombinase. This indicates that the main effect of the S-type heparin is on thrombin breakdown and that their anti-factor Xa activity, although definitely present, does not contribute much to the overall inhibition of the thrombin peak. Comparison of the IC25 values of the original enoxaparin and the fractions N6-N36 shows that the molecular species $<6,000$ are hardly active in thrombin inhibition. Because of the limited amount of material with $\mathrm{MW}>9,000$ in enoxaparin, we must conclude that the main active species must be thought to have a chainlength of between 20 and 30 saccharide units.

Our findings pertain to the question of the importance for a LMWH to have an anti-factor Xa activity. Ever since Yin (38) suggested that, to obtain adequate anticoagulation, inhibition of factor $\mathrm{Xa}$ might be a more efficient means than inhibiting thrombin, this idea has persisted in the literature (e. g. ref. 7). In fact, because factor $\mathrm{Xa}$ is only one of the three components of the prothrombin activating enzyme $(39,40)$, and because, under the conditions in clotting plasma it is not the rate limiting component (16), inhibition of factor $\mathrm{Xa}$ is an inefficient way of inhibiting thrombin generation $(12,14,40)$.

It follows from our results that a considerable amount of the activity of enoxaparin, like that of unfractionated heparin, is due to its anti-thrombin properties. It is likely to be irrelevant for the antithrombotic activity whether the generation of thrombin is inhibited or its inactivation enhanced. This seems to be in accordance with results obtained in experimental thrombosis in animals ( 1 and references therein). The fact that both oral anticoagulation and heparin treatment are effective antithrombotic strategies, although acting by completely different mechanisms, points in that direction. Probably the clinical efficacy of a LMWH is determined by a compromise between inhibitory properties, that become more pronounced with higher $\mathrm{MW}$, and pharmacokinetical proterties such as half-life time and bioavailability, that are more favourable in smaller molecules.

\section{Acknowledgements}

We thank the "Broeders van de Beijaard" for their generous donations of normal plasma and $M$. Vuilhorgne for carrying out the ${ }^{13} \mathrm{C} N M R$ analyses. The fruitful discussions with Theo Lindhout are gratefully acknowledged.

\section{REFERENCES}

1. Chesebro JH, Zoldheyi P, Badimon L, Fuster V. Role of thrombin in arterial thrombogenesis: Implication for therapy. Thromb Haemostas 1991; 66: 1-4.

2. Thunberg L, Lindah1 U, Tengblad A, Laurent TC, Jackson CM. On the molecular-weight-dependence of the anticoagulant activity of heparin. Biochem J 1979; 181: 241-3.

3. Andersson LO, Barrowcliffe TW, Holmer E, Johnson EA, Södenström G. Molccular weight dependency of the heparin potentiated inhibition of thrombin and activated factor $\mathrm{X}$. Effect of heparin neutralization in plasma. Thromb Res 1979; 15: 531-41.

4. Lane DA, Denton J, Flynn AM, Thunberg L, Lindahl U. Anticoagulant activities of heparin oligosaccharides and their neutralization by platelet factor 4. Biochem J 1984; 218: 725-32.

5. Barrowcliffe TW, Merton RE, Havercroft SJ, Thunberg L, Lindahl U, Thomas DP. Anticoagulant activities of heparin oligosaccharides. Thromb Res 1984; 34: 125-33.

6. Thomas DP, Merton RE, Barrowcliffe TW, Thunberg L, Lindahl U. Effects of heparin oligosaccharides with high affinity for antithrombin III in experimental venous thrombosis. Thromb Haemostas 1982; 47: 244-8. 
7. Bratt G, Törnebohm E, Lockner D, Bergström K. A human pharmacological study comparing conventional heparin and a low molecular heparin fragment. Thromb Haemostas 1985; 53: 208-11.

8. Hemker HC, Willems GM, Béguin S. A computer assisted method to obtain the prothrombin activation velocity in whole plasma independent of thrombin decay processes. Thromb Haemostas 1986; 56: 9-17.

9. Jesty J. Analysis of the generation and inhibition of activated coagulation factor $\mathrm{X}$ in pure systems and in human plasma. J Biol Chem 1986; 261: 8695-702.

10. Jesty J. The kinetics of inhibition of $\alpha$-thrombin in human plasma. $J$ Biol Chem 1986; 261: 10313-8.

11. Bendetowicz AV, Bara L, Samama M. The inhibition of intrinsic prothrombinase and its generation by heparin and four derivatives in prothrombin poor plasma. Thromb Res 1989; 58: 445-54.

12. Béguin S, Lindhout T, Hemker HC. The mode of action of heparin in plasma. Thromb Haemostas 1988; 60: 457-62.

13. Choay J, Petitou M, Lormeau JC, Sinay P, Casu B, Gatti G. Structure-activity relationship in heparin: A synthetic pentasaccharide with high affinity for antithrombin III and eliciting high antifactor $\mathrm{Xa}$ activity. Biochem Biophys Res Commun 1983; 116: 492-9.

14. Béguin S, Choay J, Hemker HC. The action of a synthetic pentasaccharide on thrombin generation in whole plasma. Thromb Haemostas 1989; 61: 397-401.

15. Walenga JM, Bara L, Petitou M, Fareed J, Samama M, Choay J. The inhibition of the generation of thrombin and the antithrombotic effect of a pentasaccharide with sole anti-factor Xa activity. Thromb Res 1988; 51: 23-33.

16. Hemker HC. The mode of action of heparin in plasma. XIth Congress Thrombosis Haemostasis, Brussels. Verstraete M, Vermylen J, Lijnen HR, Arnout J (eds). Leuven University Press, Leuven 1987; pp $17-36$.

17. Béguin S, Mardiguian J, Lindhout T, Hemker HC. The mode of action of low molecular weight heparin preparation (PK 10169) and two of its major components of thrombin generation in plasma. Thromb Haemostas 1989; 61: 30-4.

18. Teien AN, Lie M. Evaluation of an amidolytic heparin assay method. Increased sensitivity by adding purified antithrombin III. Thromb Res 1977; 10: 399-410.

19. Bara L, Combe-Tamzali S, Conard J, Horellou MH, Samama M. Modifications biologiques induites par trois héparines de bas poids moléculaire: PK 10169, Kabi 2165 et CY 216, comparées à l'héparine non fractionnée, injectées par voie sous-coutanée chez le volontaire sain en chirurgie générale et chez le sujet âgé en médecine. J Mal Vasc 1987; 12: 78-84.

20. Thaler E, Schmer G. A simple two-step isolation procedure for human and bovine antithrombin II/III (heparin cofactor): a comparison of two methods. Br J Haematol 1975; 31: 233-43.

21. Miller-Andersson M, Borg H, Andersson LO. Purification of antithrombin III by affinity chromatography. Thromb Res 1974; 5: 439-52.

22. Smith RL. Titration of activated bovine factor X. J Biol Chem 1973; 248: 2418-23.

23. Owren PA, Aas K. The control of dicumarol therapy and the quantitative determination of prothrombin and proconvertin. Scand J Clin Lab Invest 1951; 3: 201-18.

24. Casu B, Oreste P, Torri G, Zopetti G, Choay J, Lormeau J-C, Petitou $\mathrm{M}$. The structure of heparin oligosaccharide fragments with high anti(factor $\mathrm{Xa}$ ) activity containing the minimal antithrombin-III binding sequence. Biochem J 1981; 197: 599-609.
25. Schoen P, Wielders S, Petitou M, Lindhout T. The effect of sulfation on the anticoagulant and antithrombin III-binding properties of a heparin fraction with low affinity for antithrombin III. Thromb Res 1990; 57: 415-23.

26. Nordenman B, Danielsson A, Björk I: The binding of low affinity and high affinity heparin to antithrombin. Fluorescence Studies. Eur J Biochem 1978; 90: 1-6.

27. O'Neall-Speight M, Griffith MJ. Calcium inhibits the heparin-catalyzed antithrombin IJI/thrombin reaction by decreasing the apparent binding afinity of heparin for thrombin. Arch Biochem Biophys 1983; 225: 958-63.

28. Barrowcliffe TW, Shirle Le Y. The effect of calcium chloride on anti$\mathrm{Xa}$ activity of heparin and its molecular weight fractions. Thromb Haemostas 1989; 62: 95-954.

29. Schoen P, Lindhout P, Franssen J, Hemker HC. Low molecular weight heparin-catalyzed inactivation of factor $\mathrm{Xa}$ and thrombin by antithrombin III. Effect of platelet factor 4. Thromb Haemostas 1991; 66: $435-41$.

30. Béguin S, Wielders S, Lormeau JC, Hemker HC. The mode of action of CY216 and CY222 in plasma. Thromb Haemostas 1992; 67: 33-41.

31. Ellis V, Scully MF, Kakkar VV. The relative molecular mass dependence of the anti-factor Xa properties of heparin. Biochem $\mathbf{J}$ 1986; 238: 329-33.

32. Barrowcliffe TW, Havercroft SJ, Kemball-Cook G, Lindhal U. The effect of $\mathrm{Ca}^{+2}$, phospholipid and factor $\mathrm{V}$ on the anti(-factor $\mathrm{Xa}$ ) activity of heparin and its high-affinity oligosaccharides. Biochem $\mathbf{J}$ 198: 243: 31-7.

33. Danielsson A, Raub E, Lindahl U, Björk I. Role of ternary complexes, in which heparin binds both antithrombin and proteinase, in the accelaration of the reactions between antithrombin and thrombin or factor Xa. J Biol Chem 1986; 261: 15467-73.

34. Ofosu FA, Sie P, Modi GJ, Fernandez F, Buchanan MR, Blajchman MA, Boneu B, Hirsh J. The inhibition of thrombin-dependent positive feedback reactions is critical to the expression of the anticoagulant effect of heparin. Biochem J 1987; 243: 579-88.

35. Ofosu FA, Smith LM, Anvari N, Blajchman MA. An approach to assigning in vitro potency to unfractionated heparin and low molecular weight heparins based on the inhibition of prothrombin activation and catalysis of thrombin inhibition. Thromb Haemostas 1988; 60: $193-8$.

36. Pieters $\mathbf{J}$, Lindhout $\mathrm{T}$, Hemker HC. In situ generated thrombin is the only enzyme that effectively activates factor VIII and factor V in thromboplastin activated plasma. Blood 1989; 74: 1021-4.

37. Béguin S, Dol F, Hemker HC. Factor IXa inhibition contributes to the heparin effect. Thromb Haemostas 1991; 66: 306-9.

38. Yin ET, Wessler S, Stoll PJ. Biological properties of the naturally occuring inhibitor to activated factor X. J Biol Chem 1971; 246: 3703-11.

39. Hemker HC, Esnouf MP, Hemker PW, Swart ACW, Macfarlane RG. Formation of prothrombin converting activity. Nature 1968; 215: 246-51.

40. Rosing J, Tans G, Govers-Riemslag JWP, Zwaal RAF, Hemker HC. The role of phospholipid and factor $\mathrm{Va}$ in the prothrombinase complex. J Biol Chem 1980; 249: 7798-807.

41. Pieters J, Lindhout T. The limited importance of factor Xa inhibition to the anticoagulant property of heparin in thromboplastin-activated plasma. Blood 1988; 72: 2048-52.

Received June 4, 1991 Accepted after revision December 17, 1991 